\title{
Pengembangan Bahan Ajar Pengantar Pendidikan di Fakultas Keguruan dan Ilmu Pendidikan Universitas Batanghari Jambi
}

\author{
Buyung \\ Dosen Fakultas Keguruan dan Ilmu Pendidikan Universitas Batanghari Jambi \\ Jl. Slmat Ryadi, Broni-Jambi, Kec. Telanaipura \\ Correspondence email: buyungplaho@gmail.com
}

\begin{abstract}
This research aims to develop educational introductory teaching materials. The research method used is reaseach and development $(R \& D)$. The teaching material development model used is the Dick and Carey model. This research was conducted at the Faculty of Teacher Training and Education at the even semester 2018/2019. Retrieval of data using questionnaires, interviews and observations. The results of the study based on validation by experts were categorized as feasible with a feasibility percentage for design validation $87 \%$, media validation $90.4 \%$ and material experts $87.7 \%$. Followed by a one to one trial with a score of 93.3\%. In the small group trial with a score of 92.3\%. Then in the field trial trials (group field) with a score of $87.5 \%$. From the results of the Validation and the trials conducted, it can be concluded that the teaching and learning materials are feasible to use.
\end{abstract}

Keywords: Teaching Materials; Educational Instructional; Dick and Carey models

\section{PENDAHULUAN}

Perkembangan ilmu pengetahuan dan teknologi maju dengan cepat. Perkembangan dipacu dengan perkembangan kualitas sumber daya manusia yang selalu mencari tahu dan tidak pernah merasa puas dengan apa yang didapat untuk mencapai kebenaran yang yang hakiki. Para ilmuan terus melakukan penelitian dan percobaan untuk membukti teori-teori yang ada dan terus mencari solusi yang tepat untuk mengatasi masalah-masalah yang terjadi. Semua bidang ilmu ikut andil dalam melakukan penelitian termasuk ilmuan dari pendidikan. Para ilmuan atau ahli pendidikan terus memperbaiki pendidikan yang sesuai dengan keadaan yang terjadi ditengah-tengah masyararakat. salah femenomana yang terjadi dari segi pendidikan indonesia saat ini adalah perubahan paradigma pendidikan seperti ada perubahan kurikulum pendidikan yang terus diperbaiki untuk mendapat lulusan yang berkualitas. Hal tersebut menuntut pendidikan sebagai ujung tombak sumber daya manusia untuk ikut memperbaiki pendidikan mulai dari tingkat dasar, menengah, dan perguruan tinggi.

Perguruan tinggi merupakan salah satu penghasil tenaga pendidik (guru) harus ikut serta untuk melakukan inovasi pendidikan yang sesuai dengan keadaan yang terjadi. Sebagai salah satu penghasil tenaga pendidik (guru), sudah saatnya untuk mengkoreksi perkembangan ilmu pengetahuan dan permintaan pasar (dunia kerja). Oleh sebab, itu perguruan tinggi harus meng-update semua aktivitas mulai dari segi kurikulum, perangkat pembelajaran, proses pembelajaran, media pembelajaran dan bahan ajar. Dari segi kurikulum, salah satu mata kuliah yana data basenya FKIP adalah pengatar pendidikan. Mata kulaih pengatar merupakan mata kuliah wajib dan dasar yang wajib lulus setiap mahasiswa. Oleh sebab itu, Sesuai dengan namanya mata kuliah ini harus sesuai dengan perkembangan pendidikan. Oleh sebab itu udah selayaknya mata kuliah menjadi perhatian bagi pengajar perguruan tinggi untuk melihat fenomena yang terjadi saat ini.

Berdasarkan hasil observasi, pada proses pembelajaran masih menggunakan sumber-sumber buku terbitan lama, materi yang dipelaajri ada yang tidak sesuai dengan tuntutan pasar (dunia kerja). Kemudian berdasarkan wawancara dengan mahasiswa, materi yang dipelajari ada yang tidak relavan dengan keaadan yang terjadi saat ini. Salah satunya dalam materi ada paradigma pendidikan berpusat pada guru, namun kenyataan yang terjadi pada kurikulum K-13 semua berpusat pada siswa, sehingga perlu penambahan wawasan yang fokus pada berpusat pada siswa. Temuan ini menjadi tantangan bagi pengajar untuk memperbaiki bahan ajar pengantar pendidikan sehingga sesuai dengan kebutuhan pengguna.

Berdasarkan fakta yang diungkapkan di atas, memberikan peluang untuk melakukan penelitian pengembangan bahan ajar pengantar pendidikan di FKIP Universitas Batanghari Jambi. Dalam pengembangan perlu dikaji Bagaimanakah proses pembelajaran dan bahan ajar yang digunakan dalam mata kuliah pengantar pendidikan di FKIP Universitas Batanghari Jambi? Dan Bagaimanakah mengembangkan bahan ajar mata kuliah pengantar pendidikan di FKIP Batanghari Jambi?

Memahami pengembangan bahan ajar maka terlebih perlu memahami teori-teori tentang konsep pengembangan, Model Dick and Carey, Bahan ajar, pengantar pendidikan.

\section{Konsep Pengembangan}

Pengembangan dalam arti yang sederhana adalah suatu proses, cara pembuatan. Menurut Robet A Raiser, John V Damsy, (2007: 4) pengembangan adalah suatu pendekatan sistematis dalam desain, produksi, evaluasi dan pemanfaatan sistem pembelajaran yang lengkap, 
meliputi semua komponen sistem yang tepat dalam kontek pembelajaran. Kemudian Menurut Seel dan Richey ( 1994:34) pengembangan adalah proses penterjemahan spesifikasi desain ke dalam bentuk fisik. Sedangkan menurut Putra (2011: 133)Model pengembangan merupakan dasar yang akan dihasilkan, yang dapat berupa model prosedural, model konseptual dan model toritik.

Dalam pengembangan ada beberapa hal yang harus diperhatikan sesuai dengan pendapat Richey and Klein (2007: XV): The systematic of design, development and evaluation processs with the aim of establishing anempirical basis for the creation of instructional and non instructional products and tools and new or enhanced models that gavern their development. Ini berarti bahwa Sistem desain, pengembangan dan evaluasi yang sistematis berdasarkan data empiris untuk menciptakan produk dan alat intruksional dan produk bukan pembelajaran, model- model baru yang disempurnakan dalam mengembangankannya

Pengembangan instruksional merupakan cara yang sistematis yang dilakukan secara sadar dengan tahapan perancangan, pengembangan, evaluasi untuk menghasilkan produk, alat dan model pengembangan yang baru maupaun memperbaiki yang sudah ada (Buyung 2018: 510).

\section{Model Dick and Carey}

Model pembelajaran Dick and Carey termasuk model system pembelajaran. Pada pelaskanaanya model Dick and Carey memerlukan proses yang sistematis dan komprehensif untuk mendapatkan hasil yang optimal.

Komponen sekaligus merupakan langkah-langkah utama dari model desain sistem pembelajaran yang dikemukakan oleh Dick and Carey terdiri sepuluh langkah:

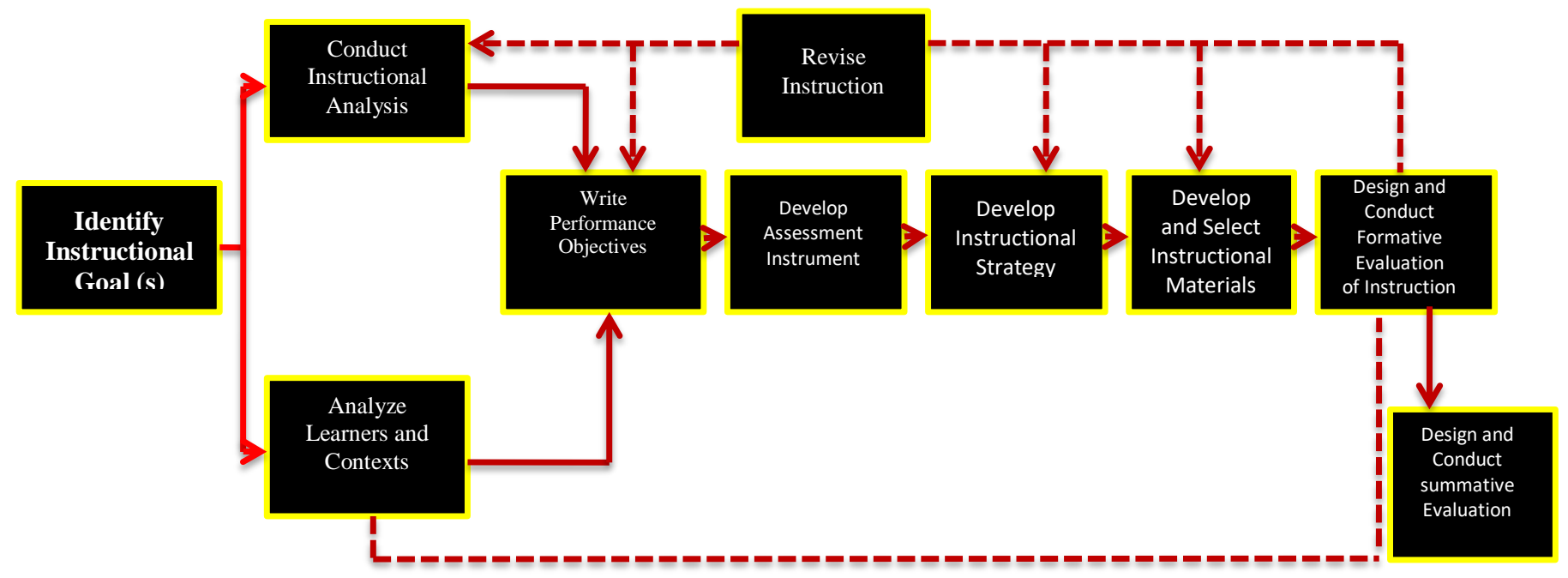

Gambar 1. Model Dick and Carey (Walter Dick, Lou Carey and James O Carey, 2005: 6)

berikut:

Dari gambar 1 dapat di deksripsikan sebagai

\section{Identifikasi Tujuan Pembelajaran (Identify Instructional Goal)}

Langkah ini merupakan penetapan rumusan tujuan pembelajaran secara umum agar dapat dikembangkan dari tujuan yang terdapat dalam silabus, analisis kinerja, maupun dimulai dari proses analisis kebutuhan serta pengalaman-pengalaman kesulitan belajar yang dihadapi mahasiswa (Walter Dick, Lou Carey and James O Carey, 2005: 6).

\section{Analisis Instruktional}

Analisis instruktional merupakan prosedur untuk melihat keterampilan dan pengetahuan responden untuk mencapai tujuan pembelajaran. Analisis instruktional perlu dikaji keterampilan, pengetahuan, dan sikap yang perlu dikuasai responden setelah mengikuti proses pembelajaran. Proses analisis instruktional menghasilkan diagram keterkaitan seluruh keterampilan,pengetahuan, sikap dan kemampuan yang dibutuhkan dalam mencapai tujuan dan kompetensi ynag ditetapkan

\section{Analisis Karakteristik Mahasiswa dan Kontek}

Analisis terhadap karakteristik mahasiswa dan konteks pembelajaran ini dapat dilakukan secara bersamaan. Analisis terhadap karakteristik mahasiswa meliputi kemampuan aktual yang dimiliki mahasiswa, gaya belajar, dan sikap terhadap aktivitas belajar. Analisis konteks meliputi kondisi-kondisi terkait dengan keterampilan, pengetahuan dan sikap yang dipelajari.

\section{Merumuskan Tujuan Instruktional Khusus}

Merumuskan tujuan instruksional khusus merupakan tujuan pembelajaran secara khusus untuk mencapai tujuan instruksional umum. Tujuan intruksional khusus terdiri atas beberapa tujuan untuk menwujudkan tujuan umum secara khusus. Oleh sebab 
itu dalam menyususn tujuan instrukisonal khusus perlu memperhatikan kemampuan yang akan dimiliki respoden setelah pembelajaran, karakterisrik responden, kriteria untuk menentukan keberhasilan dalam menwujudkan tujuan yang ditetapkan

\section{Mengembangkan Alat atau Instrumen Penilaian}

Mengembangkan alat atau instrumen penilaian merupakan instrument untuk mengukur kemampuan responden dalam menenpuhkan pembelajaran. Penilaian ini dikenal dengan evaluasi hasil belajar (Walter Dick, Lou Carey and James O Carey, 2005: 6).

\section{Mengembangkan Strategi Pembelajaran}

Pengembangan strategi pembelajaran merupakan bentuk implementasi aktivitas dalam proses pembelajaran yang terdiri dari: (1) aktivitas pra pembelajaran; (2) penyajian materi pembelajaran; dan (3) aktivitas pembelajaran tindak lanjut.

\section{Mengembangkan Bahan Ajar}

Pengembangan bahan ajar merupakan aplikasi dari Tujuan instruknal umum, analisis intruksioanl, tujuan instruknal khusus, peniaian patokan dan staregi pembelajaran. Hasil ini dirancang bahan ajar yang sesuai untuk mewujudkan tujuan yang sudah ditetapkan. Bahan ajar sudah dikembangkan dapat dapat berupa buku teks, buku panduan, modul, program audio video, bahan ajar berbasis komputer, program multimedia dan bahan ajar yang digunakan pada sistem pendidikan jarak jauh (Walter Dick, Lou Carey and James O Carey, 2005: 7)

\section{Merancang dan Melaksanakan Evaluasi Formatif}

Perancangan evaluasi dilakukan dengan membuat instrument penilaian terhadap produk yang di desain. Pada evalusi formatif dirancang dengan membuat blue print, angket untuk ahli, one to one leaner; (small group); dan (3) field trial. Evaluasi formatif dilakukan untuk mengumpulkan data yang terkait produk yang didesain. Instrumen yang sudah dirancang kemudian diujikan kepada ahli, one to one leaner; (small group); dan (3) field trial. Hasil dari evaluasi formatif dapat digunakan sebagai masukan untuk memperbaiki produk yang dikembangkan.

\section{Melakukan Revisi}

Revisi dapat dilakukan pada setiap langkah pada sesuai saran pada vealuasi formatif. Data yang diperoleh dari evaluasi formatif dikumpulkan dan ditafsirkan untuk mengetahui kekurangan terhadap produk yang dikembangkan, yang tujuannya untuk memperbaiki dan meningkatkan kualitas program pembelajaran

\section{Merancang dan mengambangkan Evaluasi Sumatif \\ Evaluasi sumatif dilakukan setelah selesai dievaluasi secara formatif, dan direvisi sesuai sarankan.}

Evaluasi sumatif tidak melibatkan perancang program, tetapi melibatkan independen. Hal ini merupakan satu alasan untuk menyatakan bahwa evaluasi sumatif tidak tergolong kedalam proses desain sistem instruktional (Walter Dick, Lou Carey and James O Carey, 2005: 7)

\section{Relevansi Model Pengembangan}

Penelitan reaseach dan development menggunakan menggunakan model Dick and Carey. Model Dick and Carey merupakan model pendekatan sistem yang tergambar secara komprehensif dari awal hingga akhir dengan langkah runtuh dan jelas, setiap laangkah tersusun secara rinci dan pengembangan instruksional sederhana dan alurnya mudah dimengerti, sehingga dapat menghasilakn output model yang mempunyai kekhasan

\section{Bahan ajar}

Bahan ajar memiliki makna yang berbeda-beda, makna yang paling banyak digunakan dalam kajian instruktional adalah;

Instructional Material we include all form of instructional such as instructor's guides, student reading list, power point presentation case studies, videos, podcast, computer-based multimedia formal, and web pages for distrence learning (Dick and carey 2009:7).

Materi Instruksional merupakan semua bentuk instruksional seperti panduan instruktur, daftar bacaan siswa, studi kasus presentasi power point, video, podcast, multimedia formal berbasis komputer, dan halaman web untuk pembelajaran berbeda.

Selain itu, Abdul Majid (2007: 174) berpendapat bahwa Bahan ajar merupakan segala bentuk bahan yang digunakan untuk membantu guru/instruktur dalam melaksanakan kegiatan pembelajaran di kelas. Bahan yang dimaksud bisa berupa bahan tertulis maupun bahan ajar tidak tertulis. Ada beberapa jenis bahan ajar (Amroi dan Ahmadi, 2010: 161 yaitu:

1. Bahan ajar pandang (visual) terdiri atas bahan cetak (printed) seperti antara lain hand out, buku, modul, lembar kerja siswa, brosur, leaflet, wallchart, foto atau gambar dan non cetak (non printed), seperti model atau maket.

2. Bahan ajar dengar (audio) seperti kaset, radio, piringan hitam dan compact disc audio.

3. Bahan ajar pandang dengar (audio visual) seperti video compact disc, film.

4. Bahan ajar multimedia interaktif (interactive teaching material) seperti CAI (Computer Assisted Instruction), Compact Disc (CD) multimedia pembelajaran interaktif dan bahan ajar berbasis web (web based learning materials). 
Pada intinya orientasi bahan ajar untuk mengoptimalkan kegiatan pembelajaran dan hasil belajar. Agar bahan ajar menjadi bermakna bagi mahasiswa, maka harus memiliki karakter tertentu untuk membedakan dengan buku teks (Pannen dan purwanto,2001: 6-8). Karakter yang dimaksud dapat dijabarkan dengan menguraikan beberapa aspek yang mendasar yang membedakan dengan buku teks.. Adapun perbedaan yang dimaksud sebagai berikut; Bahan ajar; (1) menimbulkan minat dari pembaca;(2) ditulis dan dirancang unuk digunakan mahasiswa; (3) menjelaskan tujuan instruktional; (4) disusun berdasarkan pola belajar yang fleksibel (5) disusun berdasarkan kebutuhan mahasiswa dan kompetensi yang akan dicapai; (6) berfokus pada pemberian kesempatan bagi mahasiswa untuk berlatih; (7) mengkombinasikan kesulitan belajar mahasiswa (8) selalu memberikan rangkuman; (9) gaya penulisan komunikatif dan semi formal; (10) kepadatan berdasarkan kebutuhan mahasiswa; (11) dikemas untuk digunakan dalam proses instruktional; (12) mempunyai mekanisme untuk mengumpulkan umpan balik mahasiswa; (13) menjelaskan cara mempelajari bahan ajar. Sedangkan buku teks; (1) mengasumsikan minat dari pembaca; (2) ditulis terutama untuk digunakan mahasiswa; (3) dirancang untuk dipasarkan secara luas; (4) belum tentu menjelaskan tujuan pembelajaran; (5) disusun secara linier (6) struktur berdasarkan logika bidang ilmu (content); (7) belum tentu memberi latihan, (8) tidak mengantisifasi kesulitan belajar mahasiswa; (9) belum tentu memberikan rangkuman; (10) cara penulisan bahasanya naratif tetapi tidak komunikatif; (11) sangat padat; (12) dikemas untuk dijual secara umum; (13) tidak mempunyai mekanisme untuk mengumpulkan umpan balik dari pemakai; (14) tidak memberikan saran-saran cara mempelajari buku tersebut.

\section{Pengantar pendidikan}

Dalam kamus besar bahasa indonesi, pengantar adalah pandangan umum secara ringkas sebagai pendahuluan (mengenai isi buku, ceramah, dan sebagainya) kemudian Pengertian pendidikan berdasarkan UU No.20 Tahun 2003 adalah usaha sadar dan terencana untuk mewujudkan suasana belajar dan proses pembelajaran agar pesertadidik secara aktif mengembangkan potensi dirinya untuk memiliki kekuatan spritual keagamaan, pengendalian diri, kepribadian, kecerdasan, akhlak mulia, serta keterampilan yang diperlukan dirinya, masyarakat, bangsa, dan negara.

Berdasarkan pendapat di atas dapat disimpulkan bahwa pengantar pendidikan adalah pandangan umum untuk mewujudkan pendidikan yang dilakukan secara sadar dan terencana untuk memberikan bimbingan atau pertolongan dalam mengembangkan potensi jasmani dan rohani yang diberikan oleh orang dewasa kepada anak untuk mencapai kedewasaanya serta mencapai tujuan agar anak mampu melaksanakan tugas hidupnya secara mandiri.

\section{METODE}

Pendekatan yang digunakan dalam penelitian ini adalah pendekatan sistem. Pendekatan sistem adalah serangkaian tahapan-tahapan pemecahan masalah yang setiap langkah dipahami dan menghasilkan sebuah solusi alternatif. Metode yang digunakan dalam penelitian ini adalah metode penelitian dan pengembangan $(R \& D)$. Metode $\mathrm{R} \& \mathrm{D}$ adalah metode penelitian yang digunakan untuk menghasilkan produk.

Metode yang diterapkan adalah metode penelitian dan pengembangan $(R \& D)$ yang akan menghasilkan suatu produk atau menguji keefektifan produk tertentu. Proses penelitian dan pengembangan memiliki empat tahapan yaitu pertama: studi pendahuluan, keduaa desain pengembangan, ketiga validasi evalusi formatif dan keempat implementasi. Instruem yang digunakan adalah angket. Untuk mendapatkan hasil yang maksimala makan dilakukan validasi dan evaluasi formatif yang teridir dari (1) one to one expert, yakni ahli materi, ahli desain intruksional dan ahli multimedia, (2) one to one learner, yaitu uji coba perorangan subjek yaitu tiga orang mahasiswa yang memiliki kemampuan rendah, sedang dan tinggi, (3) small group, yaitu ujicoba kelompok kecil untuk melihat kesesuaian prinsip-prinsip pembelajaran dengan pripsip penggunaan yang diujikan kepada 9 orang mahasiswa terdiri dari 3 kemampuan rendah, 3 kemampuan sedang dan 3 kemampuan tinggi, (4) field trial, yaitu ujicoba lapangan dilakukan pada 15 orang mahasiswa.

\section{HASIL DAN PEMBAHASAN Penelitian pendahuluan}

Hasil penelitian pendahuluan melaluian wawancara peneliti dengan dosen, menujukkan bahwa bahwa saat ini dosen dalam mengajar masih menggunakan referensi pengantar pendidikan yang umum dalam arti kata pengantar pendidikan yang susunan belum sesuai dengan silabus yang diberikan. Sehingga mahasiswa membutuhkan buku yang banyak untuk di jadikan referensi yang sesuai dengan silabus.

Selain itu, berdasarkan analisis angket kebutuhan mahasiswa, menunjukkan bahwa mahasiswa kawalahan dalam mencari bahan ajar karena keterbatasan materi yang sesuai dengan silabus dan keadaan. Oleh sebab itu mahsies membutuhkan bahan ajar yang relavan dan keadaan yang ada saat ini, karena ilmu selalu berkembangann sehingga dibutuhkan update secara terus menerus.

Kemudian penelitian pendahuluan berdasarkan hasil observasi didapat bahwa di fakultas Keguruan dan Ilmu Pendidikan telah tersedia beberapa fasilitas teknologi penunjang aktifitas belajar mahasiswa seperti 
Buyung, Pengembangan Bahan Ajar Pengantar Pendidikan di Fakultas Keguruan dan Ilmu Pendidikan Universitas Batanghari Jambi

infocus, jaringan internet dan falistas lain yang menunjang pembelajaran pengantar pendidikan.

\section{Mengembangkan bahan ajar dengan model Dick and Carry \\ Mengidentifikasi Tujuan Instruktional}

Secara umum, setelah mempelajari mata kuliah Pengantar pendidikan mahasiswa diharapkan dapat menerapkan dalam dalam dunia pendidikan.

\section{Analisis Instruktional}

Analisi insytruksional menghasilakn peta kompetensi dengan menggunakan kata kerja operasional adalah sebagai berikut: 1) Menjelaskan Hakikat Pendidikan, 2) Menjelaskan Pendidikan Sebagai Sebuah Sistem, 3) Menjelaskan Komponen, Fungsi dan Tujuan Pendidikan, 4) Menjelaskan Landasan Pendidikan, 5) Menjelaskan Teori dan Pilar Pendidikan, 6) Menjelaskan Teori-teori Pendidikan Pendidikan Klasik, 7) Menjelaskan Lingkungan pendidikan, 8) Menjelaskan Sistem Pendidikan nasional, 9) Menjelaskan Permasalahan pendidikan di Indonesia, 10) Menjelaskan Tokoh Pendidikan di Indonesia, 11) Mengaplikasikan Inovasi dan demokrasi pendidikan, dan 12) Menjelaskan Pendidikan dan Pembangunan.

Menganalisis karakteristik pembelajar (Analyze Learners and Contexts)

1. Perilaku Awal Mahasiswa

Kelompok yang menjadi sasaran dalam penelitian ini adalah mahasiswa program studi pendidikan matematika yang sedang menempuh mata kuliah pengantar pendidikan pada semester II

2. Karakteristik Awal Mahasiswa

Karakteristik mahasiswa yang akan menggunakan bahan yang memiliki memiliki motivasi dan kemauan yang tinggi dalam mempelajari pengantar pendidikan.

\section{Menulis Tujuan pembelajaran (Write Performance Objectives)}

Dari hasil analisis materi kuliah pengantar pendidikan, maka tujuan yang diharapkan mahasiswa dapat: 1) Menjelaskan Hakikat Pendidikan, 2) Menjelaskan Pendidikan Sebagai Sebuah Sistem, 3) Menjelaskan Komponen, Fungsi dan Tujuan Pendidikan, 4) Menjelaskan Landasan Pendidikan, 5) Menjelaskan Teori dan Pilar Pendidikan, 6) Menjelaskan Teori-teori Pendidikan Pendidikan Klasik, 7) Menjelaskan Lingkungan pendidikan, 8) Menjelaskan Sistem Pendidikan nasional, 9) Menjelaskan Permasalahan pendidikan di Indonesia, 10) Menjelaskan Tokoh Pendidikan di Indonesia, 11) Mengaplikasikan Inovasi dan demokrasi pendidikan, dan 12) Menjelaskan Pendidikan dan Pembangunan.
Mengembangkan instrumen penilaian (Develop Assessment Instruments)

Pengembangan instrumen penilaian terdiri dari ujian tengah semester, ujian semester, partsipasi dan uji kompetensi

\section{Mengembangkan Strategi Pembelajaran (Develop Instructional Strategy)}

Pengembangan strategi pembelajaran harus mempetimbgan karakteris pengguna dan strategi pembelajaran disusun berdasarkan urutan kegiatan pembelajaran yaitu tahap pendahuluan, tahap penyajian, tahap penutup, media, intrumen penialian dan alokasi waktu.

Mengembangkan dan memilih materi pembelajaran (Develop and Select nstructional Materials)

Mata kuliah Pengantar pendidikan disusun dengan memilih materi yang sesuai materi yang di ambil terdiri dari materi pembelajaran dua belas bab.

Mendesain dan melaksanakan evalusi formatif (Design and Conduct Formative Evaluation of Instruction)

Uji Ahli (One-to-one expert)

Ahli Desain Pembelajaran

Berdasarkan indikator yang dituangkan menggunakan grafik 1 .

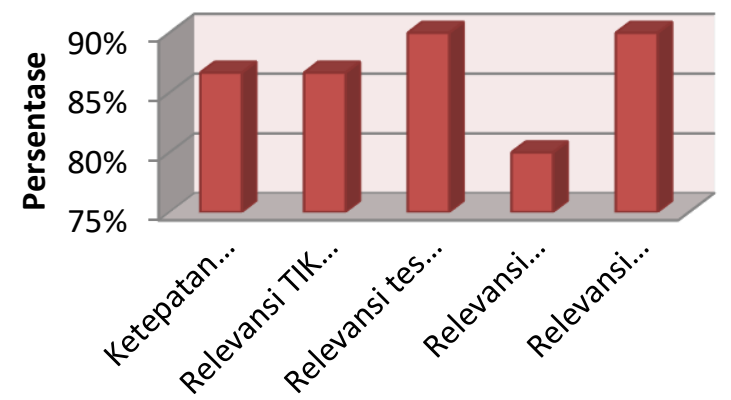

Grafik 1. Hasil Validasi Ahli Desain Pembelajaran

\section{Ahli Media}

Adapun hasil validasi oleh ahli media terhadap bahan ajar mata kuliah pengantar pendidikan dituangkan dalam bentuk Grafik 2.

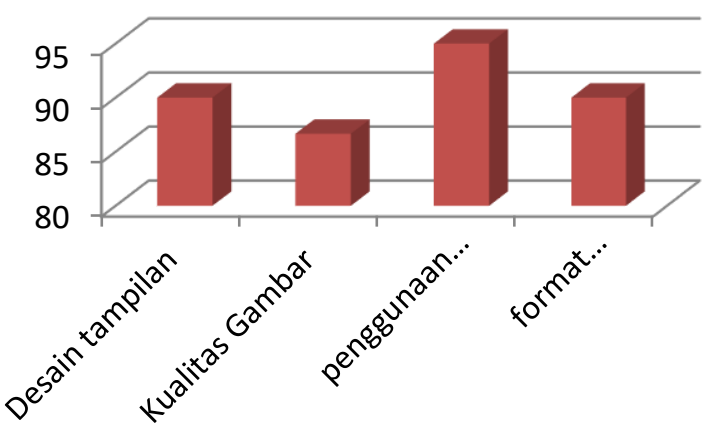

Grafik 2. hasil validasi ahli media 


\section{Ahli Materi}

Hasil validasi oleh ahli materi terhadap bahan ajar pengantar pendidikan dituangkan dalam bentuk grafik 3 .

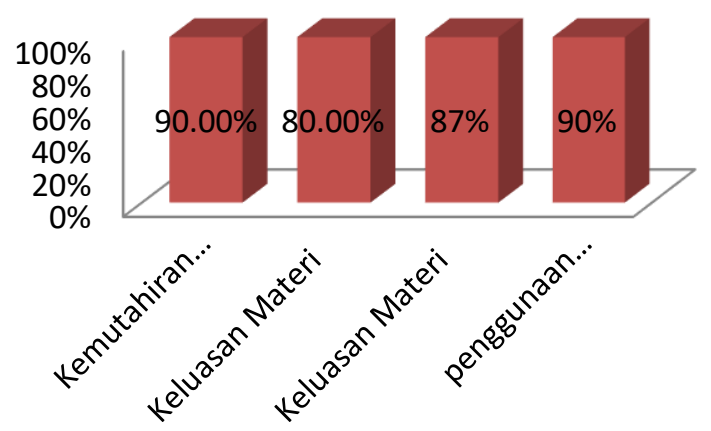

Grafik 3. Grafik Hasil Validasi Ahli materi

\section{Revisi dan Saran dari Ahli}

Ahli desain menyarankan pada tujuan instruksional khusus (TIK) perlu perbaikan kemudian pada bahasa atau kalimat perlu penegasan tujuan pembelajaran. selain itu perlu diperbaiki kalimat yang ada dimateri.

Saran dari ahli media penulisan lebih konsisten dan tata letak materi harus di atur, sein itu perlu diperhatikan kaidah bahasa indonesia yang sesuai dengan EYD dan ketepatan dalam penggunaan bahasa dalam kalimat maupun paragraf.

Saran dari ahli materi secara keseluruhan terhadap draf pengembangan bahan ajar mata kuliah pengantar pendidikan termasuk dalam kategori sangat baik. Namun dari hasil evaluasi ahli Materi perlu diperhatikan penggunaan kalimat serta kesalahan dalam pengetikan. Semua saran telah di perbaiki dan ahli merekomendasikan untuk melakukan uji perorangan.

\section{Uji coba perorangan (one to one leaner)}

Hasil tanggapan uji kelompok perorangan dapat dilihat pada gambar 4.

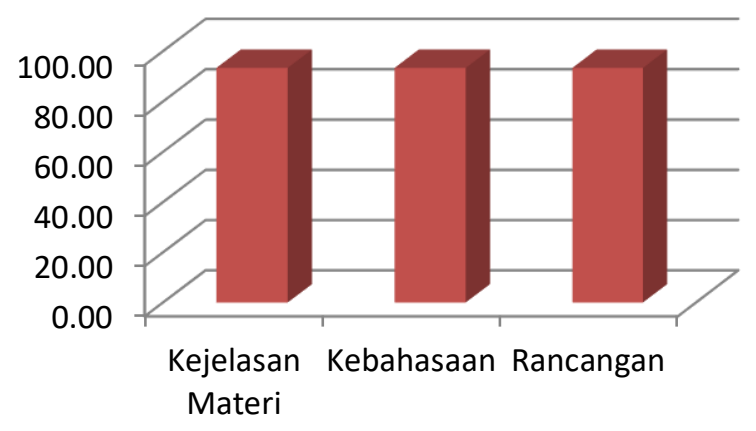

Grafik 4. uji coba perorangan.

Tanggapan pada uji perorangan adalah ada kata kata yang susah dipahami karena kata tersebut merupakan baka yang bersifat ilmiah. Kata-kata yang susah di pahami tersebut sudah diperbaiki dengan berdiskusi dengan pengguna dan telah diganti dengan bahasa yang mudah dipahami

\section{Uji coba kelompok kecil (small group)}

Hasil tanggapan uji kelompok kecil dapat dilihat pada gambar 5 berikut:

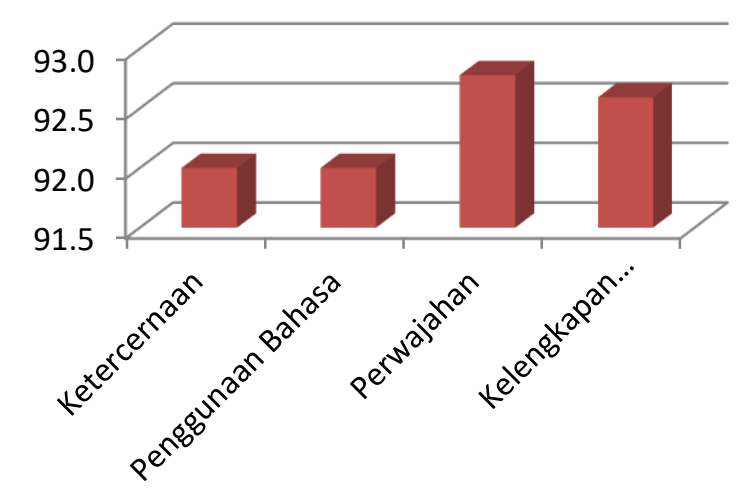

Grafik 5. hasil uji coba kelompok kecil

Tanggapan dari uji kelompok kecil yang diambil melalui angket secara kuanlitatif, sudah tidak ada masalah, sehingga disimpulkan bahan ajar layak dan dilanjutkan uji kelompok lapangan.

\section{Uji coba kelompok lapangan (field trial)}

asil tanggapan uji coba lapangan dapat dilihat pada gambar 6 berikut:

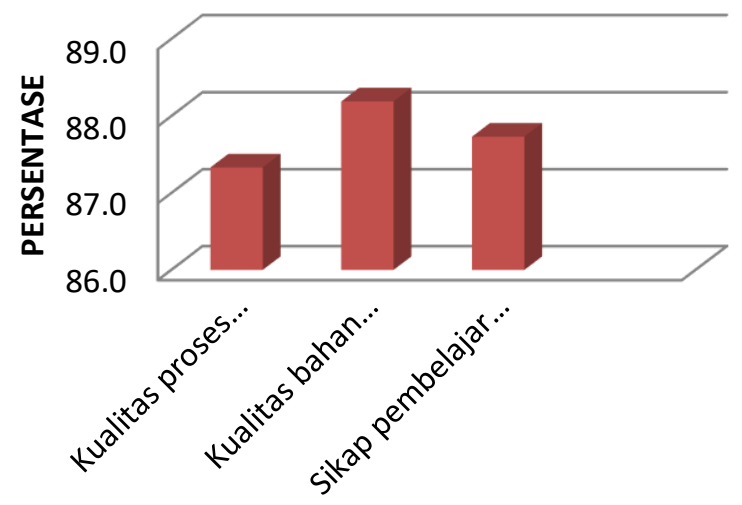

Grafik 6. hasil uji coba lapangan

Tanggapan subjek pada uji coba kelompok lapangan adalah pelaksanaan pembelajaran sudah berjalan dengan lancar dan menyenangkan, serta ditambah lagi bahan ajar yang mudah dipahami dan sesuai dengan kebutuhan subjek. Selain itu ukuran kertas yang digunakan membuat tampilan bahan ajar lebih menarik dan mudah dibawa..

\section{Pembahasan}

Peran Bahan Pembelajaran pengantar pendidikan

Fakultas Keguruan Dan Ilmu Pendidikan (FKIP) Universitas Batanghari Jambi teridir dari lima prodi yakni matematika, bahasa indonesia, sejarah, ekonomi 
dan bahasa inggris, semua prodi tersebut mendapat mata kuliah pengantar pendidikan. Namun demikian, dalam proses pembelajaran pengantar pendidikan belum ada buku yang sesuai materi ada dalam satu bahan ajar. Bahan ajar yang digunakan ada buku-buku pengantar pendidikan yang belum disusun beradasar silabus yang ditawarkan. Materi- materi yang disusun dalam buku tersebut masih terpisah materinya ketika dikaitkan dengan silabus yang ditawarkan, sehingga mahasiswa kebinggungan mencari materi dalam buku-buku tersebut, selaian itu, juga membutuh waktu untuk mencari dan biaya untuk membeli bahan ajar..

Para pelaksanaan pembelajaran akan efektif apabila diawali dengan rancangan pembelajaran yang efektif. Pandangan ini didasari pendapat jones dan davis, 2011:101)" Effective teaching begins with effective planning of instruction". Pendapat ini menegaskan pentingan rancangan dalam pembelajaran termasuk merancang bahan ajar. Bahan ajar bertujuan memudahkan mahasiwa untuk mempelajari materimateri atau informasi yang disampaikan agar dapat dipelajari secara efektif dan efisien sehingga mencapai tujuan instruksional. Untuk mendapatkan hasil yang makasimal maka diperlukan model pengembangan yang sesuai. Model pengembangan yang digunakan dalam penelitian adalah dick and carey. Karena bahwa model Dick and Carey pada setiap langkah runtuh dan jelas, selain itu model pengembangan instruksional sangat sederhana dan mudah dimengerti, serta output model ini nantinya diharapkan mempunyai kekhasan.

\section{Prosedural pengembangan Bahan ajar pengantar pendidikan matematika}

Prosedur mengembangan bahan ajar pengantar pendidikan berpedoman pada desain sistem instruksional menggunakan model Dick and Carey. Model ini memiliki 10 langkah yang dimulai dari menganalis kebutuhan dan menetapkan tmjuan intruksional umum. menentukan kemampuan atau kompetensi yang perlu dimiliki mahasiswa setelah menempuh pembelajaran. Hal ini disebut juga tujuan pembelajaran. Tujuan pembelajaran dapat dikembangkan baik dari tujuan yang terdapat dalam silabus, analisis kinerja, dan dapat pula memulai proses analisis kebutuhan serta pengalaman-pengalaman kesulitan belajar yang dihadapi mahasiswa langkah berikutnya ialah adalah melakukan analisis instruktional, yaitu sebuah prosedur untuk mengetahui keterampilan dan pengetahuan yang relevan dan diperlukan mahasiswa untuk mencapai tujuan pembelajaran. Dalam melakukan analisis instruktional, beberapa langkah diperlukan untuk mengidentifikasi kompetensi, berupa keterampilan, pengetahuan, sikap, yang perlu dimiliki mahasiswa setelah mengikuti proses pembelajaran. Kemudian malakukan analisis tujuan pembelajaran yang perlu dilakukan dalam menerapkan model ini adalah analisis terhadap karakteristik mahasiswa dan konteks pembelajaran ini dapat dilakukan secara bersamaan. Analisis konteks meliputi kondisi-kondisi terkait dengan keterampilan yang dipelajari. Analisis terhadap karakteristik mahasiswa meliputi kemampuan aktual yang dimiliki mahasiswa, gaya belajar, dan sikap terhadap aktivitas belajar. Kemuadia dilanjutkan dengan penentuan tujuan istruksional khusus untuk mencapai tujuan umum dan dalam mencapai tujuan tersebut tentu dibutuh tes acuan patokan yang menjadi acuan yang harus dipenuhi sebagai pedoman dalam menyusun materi. Setelah bahan ajar di kembangan di lanjutkan dengan evaluasi para ahli materi, desain, media untuk melihat kelayakan bahan ajar yang di buat. Selain itu untuk setiap tingkatan usia memiliki kemampuan yang berbeda dalam menganalis atau memahami suatu materi. Oleh sebab itu di lakukan uji coba dari perseorangan, kelompok kecil mauapun kelompok besar.

\section{Keterbatasan Penelitian}

Tahapan pada model Disck and Carey memiliki sepuluh langkah yang harus untuk mendapatkan hasil yang baik. Namun pada penelitian ini, dari sepuluh langkah yang ditawarkan, peneliti hanya melalukan sampai pada langkah kesembilan, pada langkah ke sepuluh yaitu melaksanakan evaluasi sumatif membutuhkan waktu yang cukup lama, yaitu sekitas 6 bulan sampai satu tahun.

\section{SIMPULAN}

1. Pada pelaksanaan pembelajaran mata kuliah pengantar pendidikan dosen dalam proses pembelajaran masih menggunakn metode konvensioanl. Selain itu bahan ajar yang digunakan dalam bentuk materi-materi yang ada belum disusun beradasar silabus. Materi- materi yang disusun dalam buku tersebut masih terpisahsehinga butuh waktu dan biaya untuk memenuhi materi yang akan dipelajari sesuai dengan silabus mata kuliah

2. pengembang bahan ajar pengantar pendidikan menggunakan model Dick and Carey yang menhasilakn produk dalam bahan ajar dalam bentuk buku. Hasil rancangan yang sudah dibuat kemudian dilakukan validasi dan evaluasi formatif. hasil evaluasi formatif dari dari beberapa validasi ahli desaian memperoleh angka $87 \%$, ahli media $90,4 \%$ dan ahli materi $87,7 \%$ dan merekomendasikan bahwa bahan ajar layak digunakan. Dan di lanjutkan dengan uji one to one memperoleh $93.3 \%$, small group 92,3\%, dan field trial $87,7 \%$ hasil ini menindikasikan bahwa bahan ajar pengantar pendidikan layak digunakan.

\section{DAFTAR PUSTAKA}

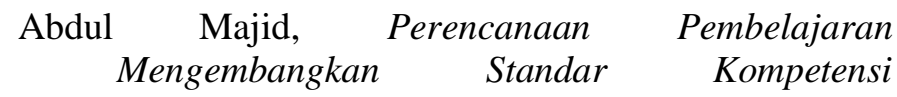


Guru,Bandung: PT. Remaja Rosdakarya Offset, 2007

Amri. dan Ahmadi. Konstruksi Pengembangan Pembelajaran: Pengaruhnya Terhadap Mekanisme dan Praktik Kurikulum, Jakarta: Prestasi Pustaka, 2010

Barbara B Seel dan Rita C Richey, Teknologi Pembelajaran; Definisi dan Kawasannya Terjemahan oleh Dewi Salma Prawiradilaga, Washington: AECT, 1994

Buyung, Pengembangan Bahan Ajar Pada Mata Kuliah Belajar Dan Pembelajaran Di Fakultas Keguruan Dan Ilmu Pendidikan Universitas Batanghari Jambi http://ji.unbari.ac.id/index.php/ilmiah/article/vi ew/517

Nusa Putra. Research \& Development, Penelitian dan Pengembangan; Suatu Pengantar, Jakarta: Raja Gradfindo, 2011

Paula Jones dan Rita Davis. 2011, Instructional Design Methods Integrating Instructional Technology, New York, Hershey: Information Science Reference, 2011

Paulina Pannen dan Purwanto, Penulisan Bahan Ajar, Jakarta: Departemen Pendidikan Nasional.,2001

Robet A Raiser, John V Damsy .Trend and Issues inIntructional Design and Technology (Boston: Pearson Education, Inc, 2007).

Walter Dick, Lou Carey, and James O Cerey. The Sistematic Design of Insruction: Sixth Edition, New York: Pearson. 2005

, The Systematic Design of Instruction, New: Jersey: Person. 2009 